\title{
Good Corporate Governance dan Operasional Perusahaan terhadap Kinerja Perusahaan
}

(Studi Pada Perusahaan Non Keuangan Yang Terdaftar di BEI Periode 2010-2019)

\author{
Aulia Claraning Sukmawati*, Oriza Herlina Amalia, Yuli Indri Sari. \\ Universitas Airlangga \\ Jl. Airlangga No.4 - 6, Airlangga, Kec. Gubeng, Kota SBY, Jawa Timur 60115, Indonesia \\ *orizaherlinaamalia@gmail.com
}

\begin{abstract}
This study aims to determine whether the components of good corporate governance, company operations and type of company ownership affect the firm's in companies listed on the Indonesia Stock Exchange. The population in this study are all companies listed as non-financial companies on the Indonesia Stock Exchange for the 2010-2019 period. The research sample was obtained by purposive sampling method, where there were 87 non-financial companies that met the sample criteria. This research was conducted using regression analysis, namely ordinary least squares $(O L S)$, which aims to determine the influence of the independent variable on the dependent variable. The results showed that the frequency of board meetings 1 had a significant negative effect as indicated by the result that the number of "medium" meetings was smaller than the number of "slight" meetings. While the frequency of meeting 2, board size, sales growth, total asset turnover have positive significant effect on firm performance and the attendance of board members, leverage, firm size, firm age and type of company ownership consistently have no effect on firm performance.
\end{abstract}

Keywords : Attendance of Board Members; Firm Performance; Frequency of Board Meetings; Sales growth; Total Asset Turnover.

\begin{abstract}
Abstrak - Penelitian ini bertujuan untuk mengetahui apakah komponen good corporate goverance, operasional perusahaan dan tipe kepemilikan perusahaan berpengaruh terhadap kinerja perusahaan pada perusahaan yang terdaftar di Bursa Efek Indonesia. Populasi dalam penelitian ini adalah perusahaan yang terdaftar sebagai perusahaan non keuangan di Bursa Efek Indonesia periode 2010-2019. Metode penentuan sampel menggunakan purposive sampling, dimana terdapat 87 perusahaan yang memenuhi kriteria sampel. Penelitian ini dilakukan dengan menggunakan analisis regresi yaitu ordinary least square (OLS), yang bertujuan untuk mengetahui pengaruh variabel independen terhadap variabel dependen. Hasil penelitian menunjukkan bahwa frekuensi rapat dewan 1 berpengaruh negatif signifikan yang ditunjukkan dengan hasil bahwa jumlah rapat "sedang" lebih kecil daripada jumlah rapat "sedikit". Sedangkan frekuensi rapat 2 , ukuran dewan, pertumbuhan penjualan, dan total perputaran aktiva berpengaruh positif signifikan terhadap kinerja perusahaan. Serta kehadiran anggota dewan, leverge, ukuran perusahaan, umur perusahaan dan tipe kepemilikan perusahaan tidak berpengaruh terhadap kinerja perusahaan.
\end{abstract}

Kata Kunci : Frekuensi Rapat Dewan; Kinerja Perusahaan; Pertumbuhan Penjualan; Total Asset Turnover.

\section{PENDAHULUAN}

Pengukuran kinerja perusahaan dapat dilakukan dengan cara membandingkan rasio-rasio antar perusahaan dalam sektor yang sejenis. Tujuannya agar investor dapat mengetahui bagaimana kondisi perusahaan pada kelompok industri tertentu untuk menentukan mana yang terbaik dan lebih menguntungkan dalam berinvestasi. Peningkatan kinerja perusahaan dapat dicapai apabila perusahaan mampu beroperasi dengan mencapai laba ditargetkan. Melalui laba yang diperoleh tersebut perusahaan akan mampu memberikan dividen kepada pemegang saham, meningkatkan pertumbuhan perusahaan dan mempertahankan kelangsungan hidupnya[1],[2].

Semakin berkembangnya perusahaan, pemilik yang sebelumnya merupakan owner-manager harus menyerahkan pengelolaan perusahaan kepada tenaga ahli di bidangnya. Hal ini bertujuan agar perusahaan dapat dikelola oleh pihak yang lebih membahami bisnis yang dijalankan sehingga dapat memaksimalkan keuntungan dengan biaya yang lebih efisien[3]. Namun pemisahan pengelolaan perusahaan ini rentan akan timbulnya agency problem, yakni perbedaan kepentingan antara pemilik (selaku pihak principal) dan manajer (selaku pihak agent). Salah satu penyebab dari timbulnya agency problem dikarenakan terdapat asymetri information, dimana manajer sebagai pihak yang paling mengerti bagaimana kegiatan operasional dan keuangan perusahaan memiliki informasi lebih daripada principal. Sehingga diperlukan adanya sebuah mekanisme untuk mengurangi kemungkinan terjadinya konflik kepentingan antar berbagai pihak. Perusahaan perlu untuk memiliki suatu sistem yang mampu mengelola perusahaan dengan baik serta memberikan perlindungan kepada para stakeholder dan para kreditur, agar mereka yakin bahwa akan mendapatkan keuntungan investasi yang bernilai tinggi dan wajar. Hal tersebut dapat diminimalisir dengan penerapan Good Corporate Governance[4], [5].

Business Innovation and Entrepreneurship Journal (BIEJ) is published under licensed of a CC BY-SA Creative Commons Attribution-ShareAlike 4.0 International License. 
Good Corporate Governance merupakan suatu proses dan struktur yang digunakan oleh organ perusahaan (pemegang saham/pemilik modal, komisaris/ dewan pengawas dan direksi) untuk meningkatkan keberhasilan usaha dan akuntabilitas perusahaan guna mewujudkan nilai pemegang saham dalam jangka panjang dengan tetap memperhatikan kepentingan stakeholder lainnya berlandaskan peraturan perundang-undangan dan nilai etika[6]. Penerapan Corporate Governance berguna untuk pengendalian dan pengaturan perusahaan yang dapat menghasilkan nilai lebih bagi stakeholder. Mekanisme pengukuran corporate governance yang digunakan adalah frekuensi rapat dewan, kehadiran anggota dewan, dan ukuran dewan. Frekuensi rapat dewan adalah berapa kali rapat dewan diadakan dalam setahun[7]. Frekuensi rapat dewan menggambarkan seberapa sering perusahaan mengadakan pertemuan antar anggota dewan untuk membahas masalah atau konflik yang sedang atau akan timbul di perusahaan. Apabila perusahaan jarang mengadakan sebuah pertemuan maka kemungkinan besar masalah atau isu yang terjadi di perusahaan tidak akan cepat teratasi dan sebaliknya. Frekuensi rapat dewan berpengaruh terhadap kinerja keuangan[8]. Hal sebaliknya ditemukan oleh Bhattacharya dan Evita \& Christina bahwa frekuensi rapat dewan tidak berpengaruh terhadap kinerja perusahaan[4], [9].

Variabel kedua yang digunakan yaitu kehadiran anggota dewan. Kehadiran anggota dewan adalah jumlah kehadiran anggota dewan pada rapat dewan yang dilaksanakan selama satu tahun[10] . Kehadiran anggota dewan merupakan hal penting, dikarenakan apabila didalam rapat dewan jumlah kehadiran dewan "kurang" maka hal ini dapat menyebabkan ketidakberhasilan tujuan yang diharapkan dari pertemuan rapat dewan dan ketidakberhasilan tersebut akan berdampak keputusan yang hendak diambil yang tentunya untuk keberhasilan perusahaan. Hal ini sejalan dengan penelitian lainnya yang menemukan bahwa kehadiran anggota dewan berpengaruh terhadap kinerja perusahaan[8]. Sedangkan hasil berbeda yaitu kehadiran anggota dewan tidak berpengaruh terhadap kinerja perusahaan[11].

Ukuran dewan digunakan sebagai variabel ketiga. Ukuran dewan adalah sekelompok orang yang dipilih oleh pemegang saham untuk menyelesaikan lembaga konflik antara perusahaan dan pemegang saham[5]. Fungsi dewan di setiap perusahaan berbeda, sehingga hasil dari setiap perusahaan juga berbeda. Dewan direksi dianggap sebagai pihak yang mampu memecahkan masalah dan konflik yang timbul di perusahaan. Semakin besar ukuran dewan maka semakin baik dalam hal pengumpulan informasiinformasi baik dari internal maupun eksternal agar permasalahan yang timbul atau akan timbul dapat teratasi dengan baik. Hal ini sejalan dengan penelitian yang ditemukan oleh Bhattacharya dan Ofoedac bahwa ukuran dewan berpengaruh terhadap kinerja keuangan[7], [10]. Namun Evita \& Christina mengemukakan bahwa ukuran dewan tidak mempunyai pengaruh terhadap kinerja perusahaan[11].

Agar perusahaan dapat dipantau perkembangannya, setiap perusahaan harus mampu membuat catatan, pembukuan, dan laporan terhadap semua kegiatan usahanya dalam bentuk laporan keuangan [8], [12]. Dengan menggunakan alat analisis laporan keuangan, dapat diketahui berbagai hal yang berkaitan dengan keuangan dan kemajuan perusahaan. Pemilik dapat mengetahui kondisi keuangan perusahaan dan menilai kinerja manjemen, apakah telah mencapai target atau tidak. Sementara itu bagi pihak manajemen, laporan keuangan merupakan cerminan kinerja mereka selama ini. Alat analisis keuangan yang biasa digunakan adalah rasio-rasio keuangan.

Rasio pertama yang digunakan dalam penelitian ini yaitu rasio leverage. Leverage merupakan rasio yang digunakan perusahaan dalam menggunakan asetnya apakah lebih banyak dibiayai oleh hutang atau dengan modal sendiri. Semakin kecil leverage maka semakin bagus, dan sebaliknya apabila leverage yang dimiliki perusahaan tinggi maka investor akan berpikir ulang untuk berinvestasi dikarenakan khawatir apabila aset yang dimiliki perusahaan didapatkan dari hutang dan perusahaan tidak mampu melunasi kewajiban pembayaran dengan tepat waktu. Hubungan signifikan terjadi antara laverage dan kinerja perusahaan[13]. Namun hasil penelitian yang ditemukan oleh Evita \& Christina serta Cadha \& Sharma menemukan bahwa leverage tidak mempunyai hubungan terhadap perusahaan[11].

Rasio keuangan selanjutnya yaitu rasio pertumbuhan penjualan, yang bertujuan untuk mengetahui pertumbuhan perusahaan dari tahun ke tahun. Pertumbuhan penjualan adalah perubahan nilai penjualan setiap tahun. Pertumbuhan penjualan dianggap mampu mencerminkan peningkatan pendapatan dan hal ini akan meningkatkan tingkat investasi yang masuk ke perusahaan tersebut dikarenakan investor mencium hal positif dari perusahaan[11]. Sehingga dapat dikatakan bahwa pertumbuhan penjualan berpengaruh terhadap kinerja 
perusahaan. Hal ini selaras dengan penelitian yang menyatakan bahwa pertumbuhan penjualan berpengaruh terhadap kinerja perusahaan[7], [10]. Sedangkan hal berlawanan ditemukan penelitian lain yang mengemukakan bahwa pertumbuhan penjualan tidak mempunyai pengaruh terhadap kinerja keuangan[11], [14].

Selanjutnya rasio keuangan yang ketiga yaitu rasio aktivitas yang diwakili oleh total asset turn over (perputaran aktiva tetap). Rasio ini digunakan untuk menilai efisiensi atau efektivitas perusahaan dalam pemanfaatan semua sumber daya atau asset (aktiva) yang dimiliki oleh suatu perusahaan. Apabila penggunaan aset perusahaan telah tergolong baik, maka keuntungan yang diperoleh perusahaan akan meningkat dan hal itu berpengaruh terhadap tingkat kepercayaan investor untuk menginvestasikan dananya ke perusahaan semakin meningkat dan tentunya menjadi nilai positif terhadap kinerja perusahaan[11], [14], [15].

Tujuan penelitian ini adalah untuk menguji hubungan antara good corporate governance dan operasional perusahaan terhadap kinerja perusahaan non keuangan yang terdaftar di Bursa Efek Indonesia periode 2010-2019. Studi ini berfokus pada frekuensi rapat dewan, kehadiran anggota dewan, ukuran dewan, leverage, sales growth dan total asset turnover. Bagian selanjutnya menyajikan landasan teori, metodologi, analisis \& pembahasan serta kesimpulan.

\section{Pecking Order Theory}

\section{KAJIAN PUSTAKA}

Pada teori ini dijelaskan bahwa perusahaan lebih memilih pendanaan internal daripada dana eksternal, hutang yang aman dibandingkan hutang yang beresiko serta yang terakhir adalah saham biasa[16], [17]. Teori pecking order menggunakan dasar pemikiran bahwa tidak ada target debt to equty ratio tertentu dimana hanya terdapat hirarkhi sumber dana yang paling disukai perusahaan. Sehingga teori pecking order membuat hirarkhi sumber dana yaitu [18], [19]: a) Sumber dana internal yang bersumber dari laba ditahan, b) Sumber dana eksternal yang bersumber dari hutang, dan c) Sumber dana eksternal yang bersumber dari saham (penerbitan saham baru).

\section{Frekuensi Rapat Dewan}

Dengan adanya aktivitas dewan direksi yang diukur dari jumlah rapat yang diadakan selama setahun bertujuan untuk pertanggungjawaban pengelolaan perusahaan dan memudahkan penelursuran serta menjamin ketaatan anggota dewan direksi terhadap seluruh peraturan dan kebijakan yang ditetapkan perusahaan. Dewan direksi bertugas untuk menentukan strategi dan kebijakan perusahaan baik jangka pendek maupun jangka panjang serta berperan untuk menyusun kebijakan operasional perusahaan serta turut mengawasi penerapan praktik good corporate governance secara optimal di setiap lini perusahaan. Frekuensi pertemuan dewan tidak dapat menghasilkan kepentingan yang sama antara pemangku kepentingan, yang mencegah mereka mencapai tujuan mereka[20], [21]. Namun hasil berbeda ditemukan bahwa ditemukan hubungan positif antara frekuensi rapat dewan direksi dengan kinerja perusahaan, dimana dewan direksi yang lebih sering melakukan rapat cenderung menghasilkan kinerja perusahaan yang lebih tinggi[22].

\section{Kehadiran Anggota Dewan}

Kehadiran anggota dewan adalah jumlah kehadiran anggota dewan direksi pada rapat dewan direksi yang diadakan dalam setahun[10], [23]. Besar kecil nya anggota dewan yang hadir dalam pertemuan akan mempengaruhi bagaimana jalannya pertemuan tersebut. Kehadiran anggota dewan menekankan fungsi dari adanya pertemuan. Apabila tidak ada cukup anggota dewan yang hadir dalam pertemuan, maka tujuan dari pertemuan hampir tidak akan tercapai dan hal tersebut tentu akan berdampak pada kinerja perusahaan apabila masalah yang dihadapi perusahaan tidak dapat teratasi[11].

\section{Ukuran Dewan}

Ukuran dewan merupakan jumlah anggota dewan direksi yang terdapat pada perusahaan. Dengan adanya dewan direksi pada suatu perusahaan, maka pengawasan kegiatan pada perusahaan dapat dilakukan dengan intensif. Hal ini dapat membuat manajer melakukan kegiatan sesuai dengan kepentingan bersama. Terdapat penelitian yang menyatakan bahwa tidak terdapat pengaruh antara ukuran dewan terhadap kinerja perusahaan[11]. Sedangkan hasil penelitan lainnya ditemukan terdapat hubungan positif antara ukuran dewan direksi dengan kinerja perusahaan[24]. Sehingga hal ini menunjukkan bahwa tinggi rendahnya jumlah dewan direksi akan meningkatkan atau menurunkan kinerja perusahaan.

\section{Leverage}

Rasio leverage digunakan untuk mengukur seberapa besar perusahaan dibiaya dengan utang [25], [26]. Debt to total aseet ratio (DAR) merupakan rasio yang menunjukkan besarnya hutang perusahaan untuk 
membiayai asset dalam menjalankan aktivitas operasionalnya. Rasio ini merupakan rasio yang mengukur perbandingan antara total utang dengan total aktiva yaitu berapa besar jumlah aset perusahaan yang didanai oleh hutang atau berapa besar aset perusahaan berpengaruh terhadap asetnya [27], [28]

Penggunaan utang yang terlalu tinggi akan membahayakan perusahaan karena perusahaan akan masuk dalam kategori extrem leverage (utang ekstrem) yaitu perusahaan terjebak dalam tingkat utang yang tinggi dan sulit untuk melepaskan utang tersebut [29]. Semakin tinggi rasio leverage, semakin buruk persepsi kinerja perusahaan[11]. Penelitian lainnya menemukan tidak terdapatnya hubungan antara leverage dengan kinerja perusahaan, dimana leverage yang tingggi mampu menyebabkan adanya konflik keagenan yang dapat menaikkan suku bunga, biaya tambahan dalam pengawasan dan penurunan investasi[12]. Sedangkan hasil berbeda ditemukan pada penelitian lainnya yang mengemukakan bahwa tidak terdapat hubungan antara leverage dengan kinerja perusahaan[30].

\section{Sales Growth}

Pertumbuhan penjualan merupakan presentase peningkatan penjualan setiap tahunnya [31]. Pertumbuhan penjualan juga dapat menunjukkan daya saing perusahaan dalam pasar. Pertumbuhan penjualan memiliki pengaruh yang strategis bagi perusahaan karena pertumbuhan penjualan ditandai dengan peningkatan market share yang akan berdampak pada peningkatan penjualan dari perusahaan sehingga akan meningkatkan profitabilitas dari perusahaan[32]. Adanya pengaruh positif signifikan antara pertumbuhan penjualan dengan kinerja perusahaan. Adanya pertumbuhan penjualan mengidikasikan bahwa profitabilitas perusahaan tersebut meningkat[33], [34]. Namun terdapat penelitian yang menemukan hasil berbeda bahwa tidak terdapatnya hubungan antara pertumbuhan penjualan dengan kinerja perusahaan, dimana pertumbuhan penjualan suatu perusahaan tidak akan menjamin bahwa kinerja perusahaan itu baik[11].

\section{Total Asset Turnover}

Total perputaran aset menggambarkan bagaimana perusahaan menggunakan keseluruhan total aset secara efektif untuk menghasilkan penjualan dan mendapatkan keuntungan[35]. Perputaran aset menunjukkan kecepatan di mana aset dikonversi atau diubah menjadi penjualan dan pada akhirnya meningkatkan profitabilitas [36], [37]. Semakin cepat suatu aktiva berputar maka akan semakin baik dan efektif penggunaan aktiva yang bersangkutan. Apabila perusahaan telah menggunakan aset dengan baik, menandakan bahwa keuntungan perusahaan akan meningkat yang akan mencerminkan kinerja perusahaan [11].

\section{METODE PENELITIAN}

Data yang digunakan adalah data sekunder yaitu data yang diperoleh dari publikasi yang diterbitkan oleh BEI berupa laporan keuangan dan laporan tahunan perusahaan manufaktur yang terdaftar di BEI (Bursa Efek Indonesia) periode 2010-2019. Populasi yang digunakan adalah seluruh perusahaan non keunagan di Bursa Efek Indonesia (BEI) dengan jumlah populasi 526 perusahaan. Pengambilan sampel dalam penelitian ini menggunakan metode purposive sampling. Pada penelitian ini terdapat kriteria untuk penentuan sampel yaitu perusahaan Non Keuangan yang terdaftar di BEI tahun 2010-2019, perusahaan yang rutin menerbitkan laporan keuangan untuk periode yang berakhir pada 31 Desember selama periode penelitian dan menerbitkan laporan keuangan dalam bentuk mata uang rupiah dan perusahaan yang menyajikan data yang mendukung mengenai variabel dalam penelitian ini. Sehingga, telah ditentukan sampel akhir pada penelitian ini adalah sebanyak 87 perusahaan dengan data observasi selama 10 tahun.

Teknik analisis data yang digunakan adalah Analisis Regresi Linear Berganda. Dalam penelitian ini menggunakan Ordinary Least Square. Adapun rumus yang digunakan adalah:

$\mathrm{ROE}_{\mathrm{i}, \mathrm{t}}=\alpha_{\mathrm{i}, \mathrm{t}}+\beta_{1}$ MEET $_{\mathrm{i}, \mathrm{t}}+\beta_{2}$ MEET $_{\mathrm{i}, \mathrm{t}}+\beta_{3} \mathrm{ATTEN}_{\mathrm{i}, \mathrm{t}}$ $+\beta_{4}$ BSIZE $_{\mathrm{i}, \mathrm{t}}+\beta_{5} \mathrm{LEV}_{\mathrm{i}, \mathrm{t}}+\beta_{6}$ SALES $_{\mathrm{i}, \mathrm{t}}+\beta_{7} \mathrm{TATO}_{\mathrm{i}, \mathrm{t}}+$ $\beta_{8} \mathrm{SIZE}_{\mathrm{i}, \mathrm{t}}+\beta_{9} \mathrm{AGE}_{\mathrm{i}, \mathrm{t}}+\beta_{10} \mathrm{TIPE}_{\mathrm{i}, \mathrm{t}}+\varepsilon_{\mathrm{i}, \mathrm{t}}$

Keterangan:

ROE $_{\mathrm{i}, \mathrm{t}} \quad=$ Kinerja perusahaan

MEET $1_{i, t} \quad=$ Frekuensi rapat dewan 1

MEET2 $2_{i, t}=$ Frekuensi rapat dewan 2

ATTEN $_{\mathrm{i}, \mathrm{t}}=$ Kehadiran anggota dewan

BSIZE $_{\mathrm{i}, \mathrm{t}} \quad=$ Ukuran dewan direksi

$\mathrm{LEV}_{\mathrm{i}, \mathrm{t}} \quad=$ Leverage

SALES $_{\mathrm{i}, \mathrm{t}}=$ Sales growth

TATO $_{i, t}=$ Total asset turnover

SIZE $_{i, t} \quad=$ Ukuran perusahaan

AGES $_{\mathrm{i}, \mathrm{t}} \quad=$ Umur perusahaan

TIPE $_{\mathrm{i}, \mathrm{t}} \quad=$ Tipe kepemilikan perusahaan

$\alpha_{\mathrm{i}, \mathrm{t}} \quad=$ Intercept

$\beta_{1-} \beta_{9} \quad=$ Koefisien regresi

$\varepsilon_{\mathrm{i}, \mathrm{t}} \quad=$ Error.

Business Innovation and Entrepreneurship Journal (BIEJ) is published under licensed of a CC BY-SA Creative Commons Attribution-ShareAlike 4.0 International License. 


\section{HASIL DAN PEMBAHASAN}

Untuk menjawab hipotesis yang telah ditentukan, maka akan dilakukan analisis regresi linier berganda. Hasil pengujian analisis regresi linier berganda dari analisis pengaruh good corporate governance dan operasional perusahaan terhadap kinerja perusahaan adalah sebagai berikut:

Tabel 1. Hasil Pengujian Statistik

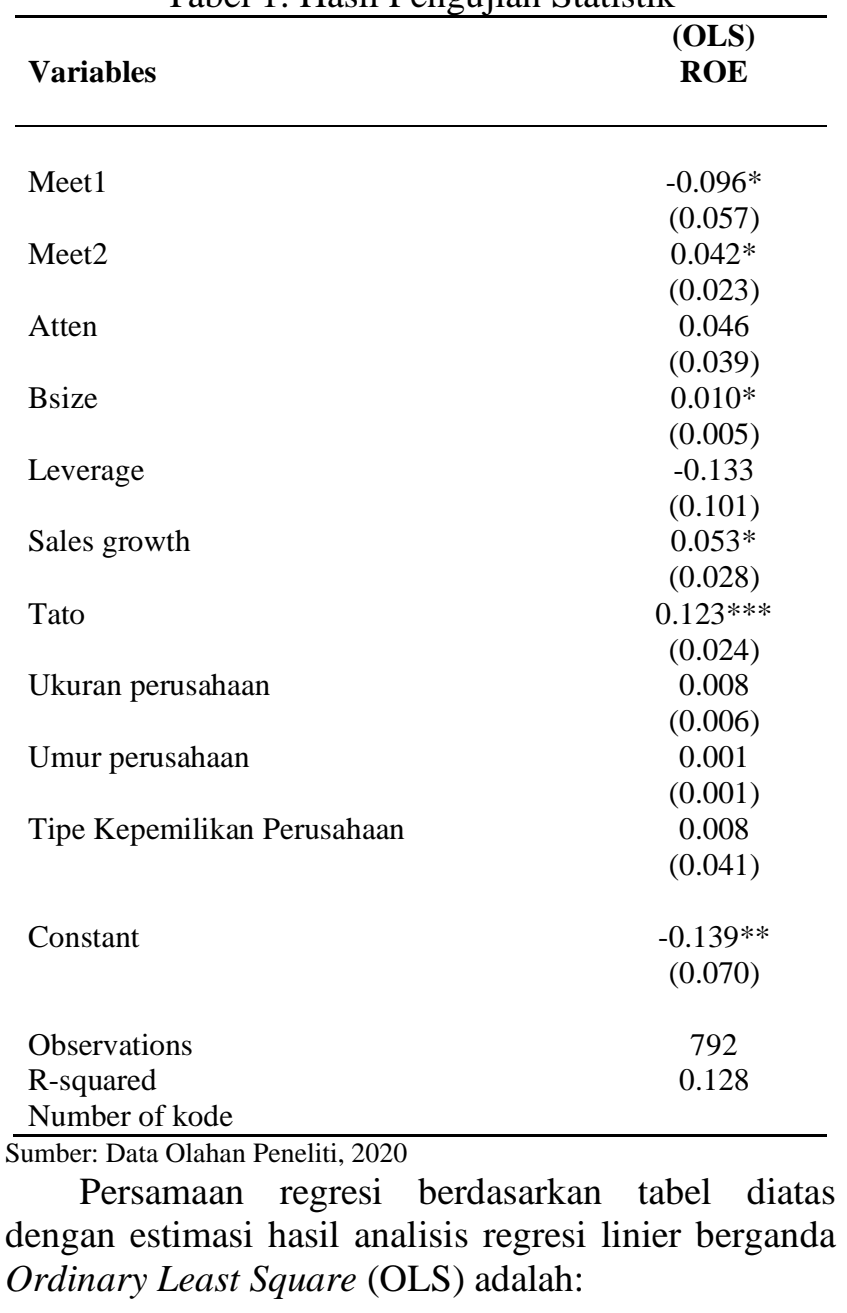

\section{ROE $=-0.139-0.096$ MEET $1+0.042$ MEET $2+$ 0.046 ATTEN + 0.010 BSIZE - 0.133 LEV + 0.053 $\mathrm{SG}+0.123$ TATO + 0.008 SIZE + 0.001 AGE + 0.008 TK}

Persamaan di atas menunjukkan hasil sebagai berikut:

a. Pengujian hipotesis secara parsial variabel frekuensi rapat dewan 1 menghasilkan $\mathrm{t}$ hitung sebesar -1.67 didapatkan dari hasil pembagian koefisien dengan standar eror dan probabilitas sebesar 0.095. Hasil tersebut menunjukkan frekuensi rapat dewan $1 \leq$ level of significant $(\alpha=10 \%)$. Hal ini berarti terdapat pengaruh negatif signifikan variabel frekuensi rapat dewan 1 terhadap variabel kinerja perusahaan.

b. Pengujian hipotesis secara parsial variabel frekuensi rapat dewan 2 menghasilkan t hitung sebesar 1.85 didapatkan dari hasil pembagian koefisien dengan standar eror dan probabilitas sebesar 0.065. Hasil tersebut menunjukkan frekuensi rapat dewan $2 \leq$ level of significant $(\alpha=$ $10 \%)$. Hal ini berarti terdapat pengaruh positif signifikan variabel frekuensi rapat dewan 2 terhadap variabel kinerja perusahaan.

c. Pengujian hipotesis secara parsial variabel kehadiran anggota dewan menghasilkan t hitung sebesar 1.16 didapatkan dari hasil pembagian koefisien dengan standar eror dan probabilitas sebesar 0.246. Hal tersebut menunjukkan kehadiran anggota dewan > level of significant $(\alpha=10 \%)$. Hal ini berarti tidak terdapat pengaruh yang signifikan variabel kehadiran anggota dewan terhadap variabel kinerja perusahaan.

d. Pengujian hipotesis secara parsial variabel ukuran dewan menghasilkan $\mathrm{t}$ hitung sebesar 1.90 didapatkan dari hasil pembagian koefisien dengan standar eror dan probabilitas sebesar 0.058. Hal tersebut menunjukkan ukuran dewan $\leq$ level of significant $(\alpha=10 \%)$. Hal ini berarti terdapat pengaruh positif signifikan variabel ukuran dewan terhadap variabel kinerja perusahaan.

e. Pengujian hipotesis secara parsial variabel leverage menghasilkan t hitung sebesar -1.32 didapatkan dari hasil pembagian koefisien dengan standar eror dan probabilitas sebesar 0.187. Hal tersebut menunjukkan leverage > level of significant $(\alpha=10 \%)$. Hal ini berarti tidak terdapat pengaruh yang signifikan variabel leverage terhadap kinerja perusahaan.

f. Pengujian hipotesis secara parsial variabel sales growth menghasilkan $\mathrm{t}$ hitung sebesar 1.88 didapatkan dari hasil pembagian koefisien dengan standar eror dan probabilitas sebesar 0.061. Hal tersebut menunjukkan sales growth $\leq$ level of significant $(\alpha=10 \%)$. Hal ini berarti terdapat pengaruh positif signifikan variabel sales growth terhadap kinerja perusahaan.

g. Pengujian hipotesis secara parsial variabel total asset turn over menghasilkan thitung sebesar 5.25 didapatkan dari hasil pembagian koefisien dengan standar eror dan probabilitas sebesar 0.000 . Hal tersebut menunjukkan total asset turn over $\leq$ level of significant $(\alpha=10 \%)$. Hal ini berarti terdapat pengaruh positif signifikan variabel total asset turn over terhadap kinerja perusahaan. 
h. Pengujian hipotesis secara parsial variabel ukuran perusahaan menghasilkan $\mathrm{t}$ hitung sebesar 1.43 didapatkan dari hasil pembagian koefisien dengan standar eror dan probabilitas sebesar 0.153. Hal tersebut menunjukkan ukuran perusahaan $>$ level of significant $(\alpha=10 \%)$. Hal ini berarti tidak terdapat pengaruh yang signifikan variabel ukuran perusahaan terhadap kinerja perusahaan.

i. Pengujian hipotesis secara parsial variabel umur perusahaan menghasilkan t hitung sebesar 1.04 didapatkan dari hasil pembagian koefisien dengan standar eror dan probabilitas sebesar 0.297. Hal tersebut menunjukkan umur perusahaan $>$ level of significant $(\alpha=10 \%)$. Hal ini berarti tidak terdapat pengaruh yang signifikan variabel umur perusahaan terhadap kinerja perusahaan.

Pengujian hipotesis secara parsial variabel tipe kepemilikan perusahaan menghasilkan $t$ hitung sebesar 0.21 didapatkan dari hasil pembagian koefisien dengan standar eror dan probabilitas sebesar 0.837. Hal tersebut menunjukkan tipe kepemilikan perusahaan > level of significant $(\alpha=10 \%)$. Hal ini berarti tidak terdapat pengaruh yang signifikan variabel tipe kepemilikan perusahaan terhadap kinerja perusahaan.

\section{Pengaruh Frekuensi Rapat Dewan 1 Terhadap Kinerja Perusahaan}

Pada penelitian ini menunjukkan hasil bahwa frekuensi rapat dewan 1 memiliki pengaruh negatif signifikan terhadap kinerja perusahaan. Adanya pengaruh negatif frekuensi rapat dewan 1 dengan kinerja perusahaan berati bahwa jumlah rapat "sedang" lebih kecil daripada jumlah rapat "sedikit". Frekuensi rapat direksi bertujuan guna pembahasan isu dan kebijakan yang sedang terjadi ataupun akan terjadi yang mampu mempengaruhi profitabilitas perusahaan. Hasil dalam penelitian ini sesuai dengan yang ditemukan oleh Vafeas bahwa terdapat hubungan negatif signifikan antara frekuensi rapat dewan dengan kinerja perusahaan[38].

Hal ini menandakan bahwa semakin sering rapat dilakukan maka akan menyebabkan turunnya nilai kinerja perusahaan. Sehingga dengan dilakukannya jumlah pertemuan yang lebih sedikit diduga karena masing-masing anggota dewan direksi telah memahami mengenai job description. Selain itu, pertemuan yang lebih sedikit diadakan juga lebih efisien dibandingkan dengan pertemuan yang sering diadakan, karena biasanya semakin sering pertemuan diadakan maka biaya terkait rapat seperti biaya makan, biaya rapat, biaya transportasi dll juga akan semakin besar dan tentunya hal itu akan berdampak negatif terhadap kinerja perusahaan.

\section{Pengaruh Frekuensi Rapat Dewan 2 Terhadap Kinerja Perusahaan}

Pada penelitian ini menunjukkan hasil bahwa frekuensi rapat dewan 2 memiliki pengaruh positif signifikan terhadap kinerja perusahaan. Adanya pengaruh positif frekuensi rapat dewan 2 dengan kinerja perusahaan yang berati bahwa jumlah rapat "banyak" lebih besar daripada jumlah rapat "sedang". Hasil dalam penelitian ini sesuai dengan yang ditemukan oleh Ntim \& Osei bahwa terdapat hubungan positif antara frekuensi rapat dewan dengan kinerja perusahaan. Hasil ini mengindikasikan bahwa dengan anggota dewan direksi lebih sering melakukan pertemuan maka kinerja perusahaan akan cenderung lebih meningkat[39].

Rapat yang rutin diadakan oleh direksi akan memberikan direksi lebih banyak waktu untuk berunding, menetapkan strategi, dan menilai kinerja manajemen [38]. Anggota direksi yang mempunyai lebih banyak waktu untuk berdiskusi guna menyamakan persepsi antar berbagai pihak akan mampu menghasilkan sebuah hasil keputusan yang tepat dan efektif bagi perusahaan karena adanya komunikasi dan koordinasi yang terjalin antar anggota direksi. Hasil dalam penelitian ini didukung oleh teori agensi bahwa anggota dewan direksi merupakan salah satu mekanisme penerapan good corporate governance yang dapat menjalankan perusahaan sesuai dengan aturan yang telah ditetapkan. Anggota dewan direksi yang lebih sering melakukan pertemuan akan meningkatkan kapasitas dirinya untuk secara efektif dalam pengawasan, pemantauan, pemberian saran dan pendisiplinan manajemen sehingga akan meningkatkan kinerja perusahaan.

\section{Pengaruh Kehadiran Anggota Dewan Terhadap Kinerja Perusahaan}

Pada penelitian ini menunjukkan hasil bahwa kehadiran anggota dewan tidak memiliki pengaruh signifikan terhadap kinerja perusahaan. Kehadiran anggota dewan adalah jumlah kehadiran anggota dewan direksi pada rapat dewan direksi yang diadakan dalam setahun ([10]. Besar kecil nya anggota dewan yang hadir dalam pertemuan akan mempengaruhi bagaimana jalannya pertemuan tersebut. Kehadiran anggota dewan menekankan fungsi dari adanya pertemuan. Apabila tidak ada cukup anggota dewan yang hadir dalam pertemuan, maka tujuan dari pertemuan hampir tidak akan 
tercapai dan hal tersebut tentu akan berdampak pada kinerja perusahaan apabila masalah yang dihadapi perusahaan tidak dapat teratasi [11].

Tidak terdapatnya pengaruh antara kehadiran anggota dewan dengan kinerja perusahaan diduga karena kehadiran anggota dewan tidak bisa dijadikan patokan untuk melihat bagaimana kinerja suatu perusahaan, masih banyak faktor lain yang dapat digunakan untuk menilai kinerja perusahaan atau bisa dikatakan bahwa nilai kehadiran anggota dewan tidak bisa dijadikan ukuran dari kinerja suatu perusahaan. Hasil dalam penelitian ini sesuai dengan yang ditemukan oleh Chou bahwa kehadiran anggota dewan tidak memiliki efek pada kinerja perusahaan, anggota dewan hanya mengawasi proses perusahaan dan menerapkan tata kelola perusahaan yang baik sesuai dengan peraturan yang ada[40].

\section{Pengaruh Ukuran Dewan Terhadap Kinerja Perusahaan}

Pada penelitian ini menunjukkan hasil bahwa ukuran dewan direksi memiliki pengaruh positif signifikan terhadap kinerja perusahaan. Terdapat hubungan positif antara ukuran dewan direksi dengan kinerja perusahaan, dijelaskan bahwa ukuran dewan direksi yang lebih besar akan memberikan pengetahuan intelektual yang lebih besar daripada ukuran dewan direksi yang lebih kecil sehingga mampu memaksimalkan pengambilan keputusan dan meningkatkan kinerja perusahaan [41]. Dewan direksi berperan penting dalam penyatuan hubungan yang terjadi diantara pemegang saham (penyedia modal) dengan orang-orang yang menjalankan modal tersebut (manajer). Jumlah anggota dewan direksi yang lebih banyak akan memberikan pertimbangan yang lebih banyak mengenai informasi serta adanya peningkatan kreativitas dan lebih fleksibel dalam pemrosesan sebuah informasi. Dikarenakan dengan adanya jumlah direksi yang lebih banyak mampu memberikan berbagai pandangan perspektif yang dapat digunakan pada proses pengambilan sebuah keputusan. Selain itu, dewan direksi akan lebih aktif dalam mengemukakan pendapat dan perspektif dalam rapat diskusi yang berlangsung sehingga akan meningkatkan objectivitas dalam hal penilaian suatu masalah serta pengurangan informasi yang bias.

\section{Pengaruh Leverage Terhadap Kinerja Perusahaan}

Pada penelitian ini menunjukkan hasil bahwa leverage tidak memiliki pengaruh signifikan terhadap kinerja perusahaan. Struktur modal merupakan faktor penting yang harus direncanakan perusahaan mengingat struktur modal menyangkut keputusan sumber dana manakah yang akan diambil perusahaan dalam menjalankan usahanya. Sumber dana perusahaan bisa berasal dari dana internal ataupun eksternal. Sumber dana internal bisa diperoleh melalui laba ditahan atau cadangan yang ada pada perusahaan.

Sedangkan sumber dana eksternal bisa diperoleh salah satunya melalui hutang. Apabila suatu perusahaan memilih untuk mendanai usahanya dengan dana yang bersumber dari eksternal, maka ia memiliki tanggung jawab pembayaran tagihan ditambah bunga pinjaman. Selain itu, leverage pada perusahaan juga mampu memberikan resiko apabila perusahaan memilih pendanaan yang berasal dari hutang. Perusahaan yang memiliki tingkat leverage yang tinggi dapat mengalami kesulitan keuangan untuk melunasi kewajiban hutangnya (resiko gagal bayar) semakin tinggi.

Hasil dalam penelitian ini sejalan dengan yang ditemukan oleh Cadha \& Sharma bahwa tidak adanya hubungan antara leverage dengan kinerja perusahaan[42]. Tidak terdapatnya pengaruh antara leverage dengan kinerja perusahaan diduga karena leverage tidak bisa dijadikan patokan untuk melihat bagaimana kinerja suatu perusahaan, masih banyak faktor lain yang dapat digunakan untuk menilai kinerja perusahaan atau bisa dikatakan bahwa nilai leverage tidak bisa dijadikan ukuran dari kinerja suatu perusahaan. Pada penelitian ini perusahaan tidak tergantung pada dana eksternal untuk mendanai perusahaannya. Apabila suatu perusahaan memiliki tingkat profitabiltas yang cenderung stabil dan meningkat, maka tentunya perusahaan tersebut memiliki tingkat kemampuan yang lebih baik dalam hal menghasilkan sebuah keuntungan.

Sebagian tingkat keuntungan yang diperoleh perusahaan akan dibagikan kepada para investor dan sebagian lagi biasanya digunakan perusahaan sebagai pendanaan internal dalam bentuk laba ditahan. Semakin tinggi tingkat profitabilitas perusahaan akan membuat sumber dana internal yang dimiliki perusahaan juga semakin besar. Penggunaan hutang yang berhasil akan meningkatkan pendapatan perusahaan karena pengambilan dana melebihi jumlah bunga yang harus dibayar, dan menjadi hak pemilik yang berarti dapat meningkatkan ekuitas perusahaan [43]. 


\section{Pengaruh Sales Growth Terhadap Kinerja Perusahaan.}

Pada penelitian ini menunjukkan hasil bahwa pertumbuhan penjualan memiliki pengaruh positif signifikan terhadap kinerja perusahaan. Pertumbuhan penjualan merupakan presentase peningkatan penjualan setiap tahunnya [44]. Pertumbuhan penjualan juga dapat menunjukkan daya saing perusahaan dalam pasar. Pertumbuhan penjualan dianggap mampu meningkatkan laba dan investasi pada perusahaan[11].

Pertumbuhan penjualan perusahaan dapat diketahui dari adanya penambahan aktiva yang dimiliki perusahaan. Pertumbuhan penjualan merupakan sebuah indikator dari pasar atas penerimaan produk atau jasa perusahaan, dimana keuntungan yang dihasilkan dari penjualan dapat digunakan untuk mengukur tingkat pertumbuhan penjualan sebuah perusahaan[1], [45]. Terdapat pengaruh positif signifikan pertumbuhan penjualan dengan kinerja perusahaan. Adanya pengaruh positif signifikan yang terjadi antara pertumbuhan penjualan dengan kinerja perusahaan diduga karena perusahaan mampu efisien dan optimal dalam penggunaan aktiva serta pemakaian sumber daya sehingga perusahaan mampu memaksimalkan penjualan untuk menghasilkan laba[42].

Meningkatnya penjualan yang diikuti serta oleh menurunnya rata-rata biaya produksi produk akan mampu memaksimalkan keuntungan yang diperoleh perusahaan. Meningkatnya keuntungan perusahaan juga akan meningkatkan dana yang dapat digunakan perusahaan untuk pembayaran dividen kepada investor ataupun sebagian dapat digunakan sebagai laba ditahan. Hal ini akan berdampak positif kepada profitabilitas perusahaan. Penjualan berbanding lurus dengan profitabilitas[46].

\section{Pengaruh Total Perputaran Aktiva Terhadap Kinerja Perusahaan}

Pada penelitian ini menunjukkan hasil bahwa total perputaran aktiva memiliki pengaruh positif signifikan terhadap kinerja perusahaan. Adanya peningkatan kemampuan yang baik ini menunjukkan bahwa perusahaan telah efektif dan efisien dalam pengelolaan dan penggunaan aktivanya. Pengelolaan aset yang dimiliki perusahaan mampu menghasilkan peningkatan kinerja perusahaan yang tercemin dari perubahan return on equity melalui perputaran asetnya sehingga berdampak kepada tingkat pengembalian (return) yang didapat investor. Apabila perusahaan terus berupaya untuk tetap meningkatkan total perputaran aktivanya dengan cara mengefektifkan dan mengefisiensikan sumber dananya, maka profitabilitas perusahaan bisa mengalami peningkatan. Semakin baik perusahaan dalam pengelolaan asetnya menjadi penjualan, maka laba yang diperoleh akan meningkat serta adanya peningkatan return yang diperoleh investor.

Dan apabila rasio total perputaran aktiva rendah, maka menunjukkan bahwa manajemen kurang efisien dalam penggunaan aset atau adanya masalah dalam produksi perusahaan. Hasil dalam penelitian ini sesuai dengan yang ditemukan bahwa terdapatnya hubungan positif antara total perputaran aktiva dengan kinerja perusahaan[42]. Perusahaan yang menggunakan asetnya secara optimal dan maksimal akan mengalami peningkatan kinerja. Total perputaran aktiva pada perusahaan juga dapat dijadikan referensi bagi para investor karena merupakan indikator apakah manajer telah menggunakan dan mengelola aktivanya secara baik atau tidak.

\section{Pengaruh Ukuran Perusahaan Terhadap Kinerja Perusahaan}

Pada penelitian ini menunjukkan hasil bahwa ukuran perusahaan tidak memiliki pengaruh signifikan terhadap kinerja perusahaan. Ukuran perusahaan merupakan nilai yang menunjukkan besar kecilnya perusahaan. Perusahaan yang memiliki banyak sumber daya menggambarkan perusahaan yang besar. Banyaknya sumber daya yang dimiliki oleh perusahaan juga berdampak pada kemampuan perusahaan untuk menguasai pasar [47].

Tidak terdapatnya hubungan antara ukuran perusahaan dengan kinerja perusahaan menandakan bahwa ukuran perusahaan bukan merupakan jaminan bahwa perusahaan akan memiliki kemampuan untuk menghasilkan keuntungan yang lebih baik. Tidak terdapatnya pengaruh bisa diakibatkan oleh semakin besar ukuran suatu perusahaan, maka perusahaan tersebut akan membutuhkan biaya yang semakin besar dalam menjalankan aktivitas operasionalnya seperti biaya tenaga kerja, biaya administrasi dan umum serta biaya pemeliharaan gedung, mesin, kendaraan dan peralatan sehingga akan mampu mengurangi profitabilitas perusahaan [48]. Selain itu, tidak adanya hubungan antara ukuran perusahaan dengan kinerja perusahaan disebabkan adanya peningkatan penjualan pada perusahaan sector non kuangan 2010-2019 yang diikuti pula dengan kenaikan biaya atau beban yang ditanggung lebih besar sehingga keuntungan yang diharapkan tidak terpenuhi. 


\section{Pengaruh Umur Perusahaan Terhadap Kinerja Perusahaan}

Pada penelitian ini menunjukkan hasil bahwa umur perusahaan tidak memiliki pengaruh signifikan terhadap kinerja perusahaan. Umur perusahaan merupakan seberapa lama perusahaan itu berdiri, berkembang dan dapat bertahan. Perusahaan yang telah lama berdiri namun tidak diikuti serta dengan peningkatan operasional perusahaan sehingga membuat produksi menurun akan mengakibatkan berkurangnya jumlah keuntungan perusahaan sehingga kualitas profitabilitas perusahaan juga bisa menurun. Umur perusahaan merupakan salah satu faktor yang dipertimbangkan oleh investor dalam berinvestasi.

Tidak ditemukannya pengaruh antara umur perusahaan dengan kinerja perusahaan membuktikan bahwa perusahaan yang berumur lama maupun perusahaan baru bukanlah suatu penentu kinerja dalam suatu perusahaan. Lama perusahaan berdiri dan survive tidak dapat memastikan baik atau buruknya kinerja perusahaan, baik perusahaan yang baru beroperasi maupun perusahaan yang cukup lama berdiri tidak menjamin akan selalu mendapatkan indicator kinerja yang lebih baik. Hasil penelitian ini sejalan dengan penelitian lainnya yang menyatakan bahwa umur perusahaan tidak berpengaruh signifikan terhadap kinerja perusahaan, lamanya perusahaan belum tentu memiliki kemampuan mengelola perusahaan yang semakin baik dan dapat memanfaatkan sumber daya yang ada untuk meningkatkan kinerja perusahaan[49].

\section{Pengaruh Tipe Kepemilikan Perusahaan Terhadap Kinerja Perusahaan}

Pada penelitian ini menunjukkan hasil bahwa tipe kepemilikan perusahaan tidak memiliki pengaruh signifikan terhadap kinerja perusahaan. Tidak ditemukannya hubungan antara tipe kepemilikan perusahaan dengan kinerja perusahaan menandakan bahwa adanya perbedaan kepemilikan perusahaan tidak memberikan efek pada penambahan atau pengurangan atas kinerja perusahaan. Dapat juga diartikan bahwa perusahaan BUMN tidak terbukti lebih baik dalam hal kinerjanya. Perusahaan dalam bentuk BUMN maupun BUMS diduga sama - sama berpotensi atau tidak menutup kemungkinan memiliki kinerja perusahaan yang baik atau buruk.

\section{KESIMPULAN DAN SARAN}

\section{Kesimpulan}

Berdasarkan hasil penelitian dapat disumpulkan bahwa variabel good corporate governance, operasional perusahaan berpengaruh terhadap kinerja perusahaan. Variable frekuensi rapat dewan diproksikan sebagai variable dummy dan ditemukan hasil bahwa frekuensi rapat dewan 1 berpengaruh negative signifikan terhadap kinerja perusahaan, hal ini bahwa semakin sering rapat dilakukan maka akan menyebabkan turunnya nilai kinerja perusahaan, semakin sering pertemuan diadakan maka biaya terkait rapat seperti biaya makan, biaya rapat, biaya transportasi dll juga akan semakin besar dan tentunya hal itu akan berdampak negatif terhadap kinerja perusahaan. Selanjutnya variable frekuensi rapat dewan 2 menghasilkan pengaruh positif signifikan terhadap kinerja perusahaan, yang berarti dengan anggota dewan direksi lebih sering melakukan pertemuan maka kinerja perusahaan akan cenderung lebih meningkat. Rapat yang rutin diadakan oleh direksi akan memberikan direksi lebih banyak waktu untuk berunding, menetapkan strategi, dan menilai kinerja manajemen.

Ukuran dewan direksi juga mempunyai pengaruh positif signifikan terhadap kinerja perusahaan, ukuran dewan direksi yang lebih besar akan memberikan pengetahuan intelektual yang lebih besar daripada ukuran dewan direksi yang lebih kecil sehingga mampu memaksimalkan pengambilan keputusan dan meningkatkan kinerja perusahaan. Selain itu, ditemukannya pengaruh positif signifikan antara pertumbuhan penjualan dengan kinerja perusahaan menandakan bahwa penjualan berbanding lurus dengan profitabilitas Semakin tinggi pertumbuhan penjualan suatu perusahaan akan membuat tingkat keuntungan yang diperoleh dari aktivitas penjualan tersebut juga akan semakin besar. Selanjutnya variable total perputaran aktiva ditemukan berpengaruh positif signifikan terhadap kinerja perusahaan, hasil dalam penelitian ini menunjukkan bahwasanya total perputaran aktiva menunjukkan nilai yang cenderung meningkat. Adanya peningkatan kemampuan yang baik ini menunjukkan bahwa perusahaan telah efektif dan efisien dalam pengelolaan dan penggunaan aktivanya.

\section{Saran}

Diharapkan dengan adanya hasil penelitian ini, perusahaan bisa dan mampu memahami tentang pentingnya penerapan good corporate governance bagi perusahaan. Perusahaan dapat lebih menjalankan tata kelola perusahaan (corporate governance) dengan baik sehingga akan tercipta peningkatan profitabilitas perusahaan serta hasil penelitian ini dapat dijadikan sebagai sumber informasi dan bahan pertimbangan 
dalam pengambilan sebuah keputusan investasi terutama dalam penilaian kinerja perusahaan. Sebaiknya peneliti selanjutnya bisa melakukan penelitian dengan menggunakan metode perhitungan kinerja perusahaan yang lain seperti retun on asset yang mungkin juga akan menunjukkan hasil yang berbeda jika menggunakan metode perhitungan tersebut serta menjadikan variabel kehadiran anggota dewan sebagai variabel dummy agar tidak banyak sampel yang terbuang sehingga bisa menghasilkan hasil penelitian yang lebih akurat.

\section{REFERENSI}

[1] A. Supriyatna, E. Yulianto, N. A. Hamdani, and G. A. F. Maulani, "Budaya Perusahaan: Penerapan Good Corporare Governance Serta Implikasinya Terhadap," Bus. Innov. Entrep. J., vol. 1, no. 1, pp. 11-20, 2019, [Online]. Available:

http://ejournals.fkwu.uniga.ac.id/index.php/BI EJ.

[2] H. Y. Su, "Business Ethics and the Development of Intellectual Capital," J. Bus. Ethics, vol. 119, no. 1, pp. 87-98, 2014, doi: 10.1007/s10551-013-1623-4.

[3] I. Muda, W. Maulana, H. S. Siregar, and N. Indra, "The analysis of effects of good corporate governance on earnings management in Indonesia with panel data approach," Iran. Econ. Rev., vol. 22, no. 2, 2018, doi: 10.22059/ier.2018.66169.

[4] M. Ilyas and M. Rafiq, "Impact of Corporate Governance on Perceived Organizational Success Department of Economics," Int. J. Bus. Soc. Sci., vol. 3, no. 13, pp. 178-187, 2012.

[5] Thomas S. Kaihatu, "Good corporate governance dan penerapannya di Indonesia," $J$. Manaj. dan Kewirausahaan, vol. 8, no. 1, p. pp.1-9, 2006, doi: 10.9744/jmk.8.1.pp. 1-9.

[6] R. Nainawat and R. Meena, "Corporate governance and business ethics," Glob. J. Manag. Bus. Stud., vol. 3, no. 10, pp. 10851090, 2013.

[7] L. E. Isaksson and A. G. Woodside, "The complexity turn to modeling firm heterogeneity in corporate social and financial performance," in The Complexity Turn: Cultural, Management, and Marketing Applications, 2017.

[8] L. E. Isaksson and A. G. Woodside, "Modeling firm heterogeneity in corporate social performance and financial performance," $J$.
Bus. Res., vol. 69, no. 9, 2016, doi: 10.1016/j.jbusres.2016.02.021

[9] Meiryani, N. A. Fitriani, and M. M. Habib, "Can information technology and good corporate governance be used by internal control for fraud prevention?," Int. J. Recent Technol. Eng., vol. 8, no. 3, 2019, doi: 10.35940/ijrte.C5503.098319.

[10] I. Lenz, H. Wetzel, and M. Hammerschmidt, "Doing Good After Doing Bad: Firm Value Implications of Distinct Corporate Social Responsibility Engagements.," AMA Winter Educ. Conf. Proc., vol. 27, 2016.

[11] E. Silvy Christina, "Do corporate governance, firm characteristics, and financial ratio affect firm performance?," in Business Innovation and Development in Emerging Economies, 2020.

[12] A. M. Sudarmadji and L. Sularto, "Pengaruh Ukuran Perusahaan, Leverage dan Tipe Kepemilikan Perusahaan Terhadap Luas Voluntari Disclosure Laporan Keuangan Tahunan," Proceeding PESAT, vol. 2, 2007.

[13] Y. Fanani, S. Sulistyo, and R. I. Mustikowati, "Pengaruh Good Corporate Governance dan Leverage Terhadap Manajemen Laba," J. Ris. Mhs. Akunt., vol. 6, no. 2, 2020, doi: 10.21067/jrma.v6i2.4218.

[14] A. Rehman and F. Hashim, "Impact of Fraud Risk Assessment on Good Corporate Governance: Case of Public Listed Companies in Oman," Bus. Syst. Res., vol. 11, no. 1, 2020, doi: 10.2478/bsrj-2020-0002.

[15] R. Purbowati, "Pengaruh Good Corporate Governance Terhadap Tax Avoidance (Penghindaran Pajak)," JAD J. Ris. Akunt. dan Keuang. Dewantara, vol. 4, no. 1, 2021.

[16] M. Z. Frank and V. K. Goyal, "Testing the pecking order theory of capital structure," $J$. financ. econ., vol. 67, no. 2, 2003, doi: $10.1016 / \mathrm{S} 0304-405 X(02) 00252-0$.

[17] A. Šestanović, Đ. Horvat, and B. Tomić, "The existence of the pecking order theory of capital structure on Croatian capital market," Ekon. Pregl., vol. 69, no. 1, 2018, doi: 10.32910/ep.69.1.4.

[18] Z. Serrasqueiro and A. Caetano, "Trade-Off Theory versus Pecking Order Theory: capital structure decisions in a peripheral region of Portugal," J. Bus. Econ. Manag., vol. 16, no. 2, 2015, doi: 10.3846/16111699.2012.744344.

[19] Suhardi and Afrizal, "Bagaimana Pecking- 
Order Theory Menjelaskan Struktur Permodalan Bank di Indonesia?," J. Ekon. dan Sos., vol. 10, no. 1, 2019.

[20] MudashiruI and Bakare, "Good Corporate Governance and Organisational Performance : An Empirical Analysis Adebayo, Mudashiru Department of Accounting and Finance Faculty of Management Sciences Lagos State University Nigeria Ibrahim, A . O . Bakare Department of Economics Facult," vol. 4, no. 7, pp. 170-178, 2014.

[21] C. Kuntadi, "Investor Reaction on the Implementation of Good Corporate Governance in Banking Companies in Asean," Webology, vol. 17, no. 2, 2020, doi: 10.14704/WEB/V17I2/WEB17018.

[22] K. Oseit and C. Ntim, "The impact of corporate board meetings on corporate performance in South Africa," African Rev. Econ. Financ., vol. 2, no. 2, 2011.

[23] S. V. T. Bhattathirippad and G. Lecturer, "Abhinav International Monthly Refereed Journal of Research in Management \& Technology Abhinav International Monthly Refereed Journal of Research In," vol. 4, no. 1, pp. 7-12, 2015.

[24] I. Ofoeda, "Corporate governance and nonbank financial institutions profitability," Int. J. Law Manag., vol. 59, no. 6, 2017, doi: 10.1108/ijlma-05-2016-0052.

[25] P. Adair and M. Adaskou, "Trade-off theory vs. Pecking order theory and the determinants of corporate leverage: Evidence from a panel data analysis upon french SMEs (2002-2010)," Cogent Econ. Financ., vol. 3, no. 1, 2015, doi: 10.1080/23322039.2015.1006477.

[26] R. Jao and G. Pagalung, "Corporate Governance, Ukuran Perusahaan, dan Leverage Terhadap Manajemen Laba Perusahaan Manufaktur Indonesia," J. Akunt. dan Audit., vol. 8, no. 1, 2011.

[27] K. Rashid, "A Comparison of Corporate Governance and Firm Performance in Developing (Malaysia) and Developed (Australia) Financial Markets," Dr. Diss. Victoria Univ., no. June, 2008.

[28] JENNY and S. CHRISTINA, "DO FINANCIAL RATIOS, FIRM CHARACTERISTICS AND CORPORATE GOVERNANCE AFFECT FIRM PERFORMANCE?," J. Bisnis dan Akunt., vol. 20, no. 1, 2019, doi: 10.34208/jba.v20i1.407.
[29] S. Carnahan, R. Agarwal, and B. Campbell, "The Effect of Firm Compensation Structures on the Mobility and Entrepreneurship of Extreme Performers," Business, vol. 561, no. December 2007, pp. 1-43, 2010, doi: $10.1002 / \mathrm{smj}$.

[30] Z. Sulong, J. C. Gardner, A. H. Hussin, Z. M. Sanusi, and C. B. Mcgowan, "Managerial Ownership, Leverage and Audit Quality Impact on Firm Performance:-Evidence From the Malaysian Ace Market," Account. Tax. •, vol. 5, no. 1, 2013.

[31] "THE EFFECT OF CAPITAL INTENSITY, EXECUTIVE CHARACTERISTICS, AND SALES GROWTH ON TAX AVOIDANCE," J. Appl. Financ. Account., vol. 7, no. 1, 2020.

[32] W. Anindya and E. N. A. Yuyetta, "Pengaruh Leverage, Sales Growth , Ukuran Perusahaan Dan Profitabilitas Terhadap," Diponegoro J. Account., vol. 9, no. 3, 2020.

[33] N. P. D. Pratiwi, I. N. K. A. Mahaputra, and I. M. Sudiartana, "Pengaruh Financial Distress, Leverage dan Sales Growth terhadap Tax Avoidance Pada Perusahaan Manufaktur yang Terdaftar di BEI Tahun 2016," J. Kharisma, vol. 2, no. 1, 2020.

[34] S. S. Jaiswall and K. K. Raman, "Sales Growth, CEO Pay, and Corporate Governance in India,' J. Accounting, Audit. Financ., vol. 36, no. 2, 2021, doi: 10.1177/0148558X19825672.

[35] H. Supardi, H. S. H. Suratno, and S. Suyanto, "PENGARUH CURRENT RATIO, DEBT TO ASSET RATIO, TOTAL ASSET TURNOVER DAN INFLASI TERHADAP RETURN ON ASSET," JIAFE (Jurnal Ilm. Akunt. Fak. Ekon., vol. 2, no. 2, 2018, doi: 10.34204/jiafe.v2i2.541.

[36] H. Supardi and H. Suratno, "PENGARUH CURRENT RATIO, DEBT TO ASSET RATIO, TOTAL ASSET TURNOVER DAN INFLASI TERHADAP RETURN ON ASSET," J. Ilm. Akunt. Fak. Ekon., vol. 2, no. Tahun, 2016.

[37] N. O. Damayanti and S. Sitohang, "Pengaruh Current Ratio, Inventory Turnover, Dan Total Asset Turnover Terhadap Return on Asset," J. Ilmu Dan Ris. Manaj., vol. 08, no. 06, 2019.

[38] N. Vafeas, "Board meeting frequency and firm performance," J. financ. econ., vol. 53, no. 1, 1999, doi: 10.1016/S0304-405X(99)00018-5.

[39] C. G. Ntim and K. A. Osei, "The Impact of Corporate Board Meetings on Corporate 
Performance in South Africa," African Rev. Econ. Financ., vol. 2, no. 2, 2011.

[40] H. I. Chou, H. Chung, and X. Yin, "Attendance of board meetings and company performance: Evidence from Taiwan," J. Bank. Financ., vol. 37, no. 11, 2013, doi: 10.1016/j.jbankfin.2013.07.028.

[41] B. Jackling and S. Johl, "Board structure and firm performance: Evidence from India's top companies," Corp. Gov. An Int. Rev., vol. 17, no. $4, \quad 2009$, doi: $10.1111 / \mathrm{j} .1467-$ 8683.2009.00760.x.

[42] S. Chadha and A. K. Sharma, "Capital Structure and Firm Performance: Empirical Evidence from India," Vis. J. Bus. Perspect., vol. 19, no. 4, 2015, doi: $10.1177 / 0972262915610852$.

[43] N. Warningtias and Musdolifah, "Analisis Faktor-Faktor Yang Mempengaruhi Kinerja Keuangan Perusahaan Sektor Property Dan Real Estate Yang Terdaftar Di Bursa Efek Indonesia (Bei) Periode 2011-2015," J. Ilmu Manaj., vol. 4, no. 3, 2016.

[44] H. Short and K. Keasey, "Managerial ownership and the performance of firms: Evidence from the UK," J. Corp. Financ., vol. 5, no. 1, 1999, doi: 10.1016/s09291199(98)00016-9.

[45] A. Solihat, "Layanan Purna Jual pada Produk Otomotif," Bus. Innov. Entrep. J., vol. 1, no. 1, pp. 6-10, 2019, [Online]. Available: http://ejournals.fkwu.uniga.ac.id/index.php/BI EJ.

[46] Eugene F. Brigham dan J.F. Houston, "DasarDasar Manajemen Keuangan. Edisi 11.," Jakarta : Salemba Empat, 2010.

[47] A. J. Saputra and S. Salim, "Pengaruh Profitabilitas, Leverage, Farm Size, dan Sales Growth Terhadap Financial Distress," Multiparadigma Akunt. Tarumanagara, vol. 2, no. $1,2020$.

[48] "PENGARUH GOOD CORPORATE GOVERNANCE, UKURAN PERUSAHAAN, LEVERAGE DAN PROFITABILITAS PADA TAX AVOIDANCE," E-Jurnal Akunt., vol. 2017, no. 1, 2017.

[49] A. A. Yemane, M. Lakshmipathi Raju, and R. Madhusudana Raju, "The impact of corporate governance on firm performance: Evidence from ethiopian insurance companies," Res. J. Financ. Account., vol. 11, no. 2, 2015. 